\title{
PHAGOCYTES - CELLS OF NONSPECIFIC AND SPECIFIC RESISTANCE
}

\author{
K.G. GARKAVA \\ National Aviation University, Kyiv
}

The analysis of the functional activity of neutrophils and macrophages has been conducted. It is shown that being effectors of natural resistance in the immune system their functions are different. Neutrophils are a kind of helpers for macrophages, enhancing their phagocytic, antigen presenting and immunoregulatory functions.

Keywords: neutrophils, macrophages, resistance, immune system.

Introduction. The modern teaching of phagocytosis covers a wide range of problems - from molecular mechanisms of conjugation, the incentive effect to general pathological concepts. Any process aimed at restoring structural homeostasis begins and ends with phagocytic reaction. This is due to the fact that, firstly, phagocytes determine baseline resistance, and, secondly, mediate the activity of other effectors of cellular and humoral nature. Modern ideas about the role of phagocytic cells in nonspecific and specific resistance indicate that their function is not only to absorb, kill and digest heterogeneous agents, but also participate in a wide range of general biological reactions to restore homeostasis in the organism $[3,5,6,10,11,12]$.

Literature analysis. Phagocytes are cells of bone marrow nature, which characterized by well-developed cytoplasm synthesizing apparatus and wide complex lysosomes. They are characterized by well-developed cell periphery, which provides phagocytosis, pinocytosis, secretion and movement in space. Population of phagocytes is functionally and morphologically heterogeneous, reflecting stage of the life cycle, in which is a specific cell. Cells capable for phagocytosis are divided into two main categories - microphages (granulocytes) and macrophages (blood 
monocytes and tissue macrophages). Despite that macrophages and neutrophils are effectors of natural resistance in the immune system their functions are different. Neutrophils that make up 50-70\% of blood cells are the largest subpopulation of blood cells. The primary function of neutrophils is inflammation and production of large amounts of biologically active mediators $[3,5,6,11,12,18,20]$.

Neutrophils. Physiological capabilities of neutrophils are especially manifested in the areas of inflammation. Experience has shown that neutrophils may substantially be restructured or conditioned under the influence of endogenous and exogenous incentives. From the biological side these incentives are united because both actively interact with receptors of neutrophils - a starting point from which mobilization of their cytopathogenic and phlogogenic potential is started. Significant number of receptors for biologically active substances with different mechanisms of action of catecholamines, corticosteroids, prostaglandins, histamine, fibronectin, and other substances are expressed on neutrophil cytoplasmic membrane. The presence of these receptors largely determines the reactivity of neutrophils to a specific set of functional modulators [7,9]. Signals from different receptors cause uneven reactions: $\beta$-adrenergic stimulation and processing with $\mathrm{E}$ prostaglandin reduce the intensity of secretion but cholinergic agents, conversely, increase this process $[3,5,6]$.

Some enzymes and other biologically active substances that are found in the cytoplasm of neutrophils are: acid phosphatase, acid ribonuclease, acid deoxyribonuclease, cathepsin B, C, D, E; phosphoprotein phosphatase, myeloperoxidase, hyaluronidase, lysozyme, collagenase, phospholipase, acid lipase, lactoferrin, phenacetin (and other antibacterial proteins), endogenous pyrogens, plasminogen activator, hemolysin, glycoprotein and basic proteins [3,5,6,11,12].

Neutrophils have inside a different by chemical composition and direction of action compounds by which they may affect different mediator systems (complement, immunoglobulins, blood clotting, fibrinolysis, kallikrein-kinin) and cells (macrophages, lymphocytes, granulocytes, platelets, endotheliocytes, fibroblasts) blood and connective tissue, and the nervous and endocrine system. In these contacts neutrophils are not only effectors, but also a target. Oxygen-dependent bactericidal 
activity of neutrophils caused by primary active oxygen forms - superoxide anion $\left(\mathrm{O}_{2}^{-}\right)$, singlet oxygen $\left({ }^{1} \mathrm{O}_{2}\right)$, hydroxyl radical $\left(\mathrm{OH}^{-}\right)$, hydrogen peroxide $\left(\mathrm{H}_{2} \mathrm{O}_{2}\right)$ and secondary metabolites of activated oxygen (hypochlorous acid, chloramines, products of lipid peroxidation). Similar events occur in macrophages [3,5,6,10,12 ].

Neutrophils produce cytokines with known structure and function: IL-1, IL-3, IL-6, IL-8, TNF, GM-CSF [20] receptor antagonist IL-1R, lymphocyte activating factor [17], phagocyte stimulating factor [14].

In the recent years experiments were demonstrated the existence in neutrophils of another oxygen-dependent mechanism of antimicrobial protection, which includes the ability to "throw" net-like formations, in which microorganisms traped, neutralized, and then killed. These structures are called - neutrophil extracellular traps. They consist of nucleic acids and enzymes secreted by neutrophils in response to microbial and nonmicrobial promoters $[2,4,19]$.

Neutrophils are helpers for macrophages [3,7,9] and when entering the inflammation area they phagocytize products of neutrophil decomposition, may produce immunogenic form of the antigen and present it to lymphocytes.

Macrophages. Due to the wide resettlement of tissue macrophages (table 1) in the body and the circulation of blood monocytes they take a number of regulatory functions that control the processes of lymphocytes proliferation, differentiation and functions.

Macrophages as an alarm-cell may contribute to the mobilization and activation of a population of lymphocytes, granulocytes and fibroblasts. Effects of macrophages on proliferation, differentiation and function of macrophages themselves, their precursors and different populations of lymphocytes can be stimulating or inhibiting. Under phagocytosis there is increase of production of prostoglandins E, which activate membrane adenylyl cyclase of macrophages, leading to increasing intracellular cAMP and inhibition of macrophage function. Selective inhibition of macrophage synthesis of PG- E can lead to amplification of the immune response and therefore establishing two-way communications regulator between macrophages and lymphocytes [5,6,10]. 
There are receptors on macrophages for Fc- fragment of immunoglobulin $\mathrm{G}$, to the C3 component of complement to histamine before transplantation antigens and several interleukins, and is adaptive hormone receptors [1], partly for adrenaline. This includes macrophages for adaptation reactions of the whole organism. Under the influence of foreign agents all phagocytes produce free radicals, NO, cytokines, chemokines and thus trigger innate and acquired immunity [ 10,11,12].

Macrophages in different tissues

\begin{tabular}{|l|l|}
\hline \multicolumn{1}{|c|}{ Tissue } & \multicolumn{1}{c|}{ Cells } \\
\hline Bone marrow & Promonocytes, monocytes \\
\hline Blood & Monocytes \\
\hline Lungs & Alveolar macrophages (mobile) \\
\hline Spleen & Spleen macrophages (mobile and fixed) \\
\hline Lymph nodes & Lymph nodes macrophages (mobile and fixed) \\
\hline Bone tissue & Osteoclasts \\
\hline Nervous tissue & Microglia \\
\hline Connective tissue & Histiocytes \\
\hline Peritoneal cavity & Moving macrophages, peritoneal exudate \\
\hline Liver & Kupffer cells macrophages of sinuses \\
\hline
\end{tabular}

During the development of the immune response macrophages acquire a different phenotype M1 and M2. The classic type macrophages M1 produce proinflammatory cytokines such as - IL-1, TNF $\alpha$, IL-6, IL-12, IFN $\gamma$, and also generate reactive oxygen forms. These macrophages have high phagocytic and bactericidal properties and thereby destroy intracellular microorganisms. Alternative M2 phenotype of macrophages destroys extracellular parasites - worms, fungi and provides angiogenesis, repair and remodulation of tissues, but herewith it may activate the tumor growth. M2 macrophages produce anti-inflammatory cytokines such as IL-10 and IL-13 [13,15,16]. 
M1 macrophages are integrated into the cellular immunity and M2 phenotype macrophages - in humoral immune response. The spectrum of cytokines produced by M1 macrophages similar to cytokines that produce Th1, and M2 macrophages - to Th2 cytokines [16].

Inductive phase of the immune response begins after the first exposure to an antigen. The basic cells of this phase are macrophages, namely antigen presenting cells that perform phagocytosis, processing and presentation of antigenic material fot $\mathrm{T}$-helpers cells. The process of antigen recognition by $\mathrm{T}$-helper cells is a contact between antigen distinctive receptor of T-helper cells on one side and a set of phagocyte "HLA II + antigen" - on the other. Antigen recognition by T-killer is provided by the interaction between antigen receptor identification of T-killer on the one hand and complex "HLA I + antigen" - on the other. The principle of double recognition is necessary to provide the specific interaction of own immune cells.

Under the influence of IL-12 and $\gamma$-INF T-helper cells differentiate into T-helper 1 and under the influence of IL-4 and IL -10 T-helper cells differentiate into T-helper 2.

When T-helper 1 is stimulated there is an activation of cell response, when T-helper 2 - there is an activation of humoral response $[11,12]$.

M1 phenotype macrophages activate antitumor immunity and M2 phenotype macrophages suppress it. Repolarization of hypoxic macrophages from phenotype M2 to M1 by bacterial biopolymers applied alone or with cytotoxic medicine NSC631570 results in the inhibition of tumor growth [8].

Thus functions of phagocytes in the organization of the immune response are very diverse. Neutrophils in inflammation area form the vanguard line of defense. At the same time, these cells possessing powerful cytotoxicity apparatus and are actively involved in the pathogenesis of the inflammatory process, largely determining its development and outcome. In those cases where the activated neutrophils secrete large quantities of collagen and elastinolytic enzymes and for some reason are not replaced by monocytes (macrophages), the center of acute inflammation is transformed into an abscess. Having appeared in the hearth of purulent inflammation, 
mononuclear phagocytes abruptly change its further course. On the one hand, they can maintain tissue alteration, running by neutrophils, although the implementation of the cytotoxic potential of macrophages, unlike neutrophils, does not have explosive character. On the other hand, and most significantly, macrophages are included in genetically determined program of tissue repair. They stimulate the growth of fibroblasts, smooth muscle cells, and endothelial cells, accelerate the regeneration of capillaries disinhibiting collagenase, as well as the synthesis of other components of connective tissue matrix. Macrophages lead the recovery period until the very end, participating in the final chord of reparative regeneration of the secondary-modeling of fibrous tissue and its approximation to the original architectonic $[5,6]$.

\section{CONCLUSIONS}

1. Phagocytes ensure the development of the inflammatory response.

2. Phagocytes kill bacteria, eliminate from the body altered own tissues and cells.

3. Phagocytes participate in cell-mediated immunity: provide digesting of foreign agent, present antigenic material and regulate the activity of T-cells.

4. Phagocytes activate humoral immunity.

5. Phagocytes provide anti-tumor immunity and cytotoxicity.

6. Phagocytes regulate kinin system and homeostasis.

\section{REFERENCES}

1. Афанасьев Ю.И. Структура и функции макрофагов / Ю.И. Афанасьев, В.И. Ноздрин, М.З. Бахшинян, В.Л. Горячкина // Успехи современной биологии. - 1982. - т.93., №3. - С. 421-432.

2. Долгушин И.И. Нейтрофильные ловушки и методы оценки функционального статуса нейтрофилов / И.И. Долгушин, Ю.С. Андреева, А.Ю. Савочкина. - М.: УроРАН, 2009. - 203 с.

3. Долгушин И.И. Нейтрофилы и гомеостаз / И.И. Долгушин, О.В. Бухарин. - Екатеринбург: УроРАН, 2001. - 232 с. 
4. Долгушин И.И. Кислородзависимый метаболизм интактних и активированных нейтрофильных гранулоцитов слюны / И.И. Долгушин, В.А. Маркова, А.Ю. Савочкина, И.В. Пегушина // БЭБМ. - 2013. - №8. C. 206-208.

5. Маянский А.Н. Реактивность нейтрофила / А.Н. Маянский, А.Н. Галиуллин. - Казань: Изд-во Казан. ун-та, 1984. - 158 с.

6. Маянский А.Н. Очерки о нейтрофиле и макрофаге / А.Н. Маянский, Д.Н. Маянский. - Новосибирск: Наука, 1989. - 254 с.

7. Пигаревский В.Е. Гипотеза о резорбтивной клеточной резистентности как особой форме антимикробной зашиты организма / В.Е. Пигаревский // Арх.патологии. - 1992. - т.54, №8. - С. 40-45.

8. Сківка Л.М. Модуляторний і комодуляторний вплив препарату NSC631570 на функціональну активність макрофагів мишей in vitro / Л.М. Сківка, В.В. Позур, М.П. Рудик, О.Г. Федорчук, М.Ю. Гром // ДАН. - 2012. - №7. C. $164-169$.

9. Ткаченко С.Б. Дефенсин нейтрофилов моделирует функциональную активность моноцитов / [С.Б. Ткаченко, О.В. Фесенко, Е.А. Корнева и др.] // БЭБМ. - 1993. - т.116, №11. - С. 674-476.

10. Фрейдлин И.С. Система мононуклеарных фагоцитов / И.С. Фрейдлин. М.: Медицина, 1984. - 277 с.

11. Хаитов Р.М. Экологическая иммунология / Р.М. Хаитов, Б.В. Пинегин, Х.И. Истамов. - М.: Медицина, 1995. - 474 с.

12. Хаитов Р.М. Современные представления о защите организма от инфекции / Р.М. Хаитов, Б.В. Пинегин // Иммунология. - 2000. - №1. C. 61-64.

13. Goldman O. Transcriptome Analisis of Murine Macrophages in Response to Infection with Streptococcus pyogene Reveals an Unusual Activation Program / [O. Goldman, M. von Kockritz-Blickwede, C.Holtge et al.] // Infect. Immun. 2007. - Vol.75, N8. - P.4148-4157.

14. Ishibashi Y. Phagocytosis-stimulating factor derived from polymorphonuclear neutrophils / Y. Ishibashi, T. Yamashita // Sakagu. - 1989. - Vol. 61, N1. - P. 21-26.

15. Martinez F.O. Macrophage activation and polarization / [F.O. Martinez,
[F. A.Sica, A. Mantovani et al.] // Front Biosci. - 2008. - Vol.13. - P. 453-461.

16. Oosterhout A.J.M. Th1 /Th2 paradigm: not seenig the forest for the trees? / A.J.M. Oosterhout, A.C. Motta // Eur.Respir J. - 2005. - Vol.25. - P. 591-593.

17. Sheng Y.Y. Rat and human polymorphonuclear leukocyte derived lymphocyte stimulatory factors / Y.Y. Sheng, Y. Bird, F. Pompidoy // Biomed. Pharmacother. - 1984. - Vol.38, N6. - P. 304-308. 
18. Tan B.H. Macrophages aquil neutrophil granules for antimicrobial activity against intracellular pathogens / [B.H. Tan, C. Meincen, M. Bastian et al.] // J.Immunol. - 2006. - Vol. 177. - P. 1864-1871.

19. Papaynnopoulos V. Neutrophil elastase and myeloperoxidase regulate the the formation of neutrophil extracellular traps / [Venerelos Papaynnopoulos, D. Kathleen, Abdul Hakkimi Metzler et al.] // J. Cell Biol. - 2010. - Vol.191, N3. P. 677-691.

20. Yoshimura A. Secretion of IL-1 Beta, TNF-alpha, IL-8 and IL-1 by human polymorphonuclear leukocyte in response to lypopolysaccharides from periodontopathic bacteria / A. Yoshimura, Y. Hara, T. Kaneko, I. Kato // J. Periodontal. Res. - 1997. - Vol.32, N3. - P. 279-286.

\title{
ФАГОЦИТЫ - КЛЕТКИ НЕСПЕЦИФИЧЕСКОЙ И СПЕЦИФИЧЕСКОЙ РЕЗИСТЕНТНОСТИ
}

\author{
К.Г. ГАРКАВАЯ
}

Национальный авиационный университет, г. Киев

Проведен анализ функциональной активности нейтрофилов и макрофагов. Показано,что являясь эффекторами природной резистентности в имунной системе их функиии отличаются. Нейтрофиль - это своеобразные хелперы для макрофагов.Они усиливают их фагоцитарную, антигенпредставляющую и иммунорегуляторную функиии.

Ключевые слова: нейтрофиль, макрофаги, резистентность, иммунная система.

\section{ФАГОЦИТИ - КЛІТИНИ НЕСПЕЦИФІЧНОЇ І СПЕЦИФІЧНОЇ РЕЗИСТЕНТНОСТІ}

\author{
К.Г. ГАРКАВА
}

Національний авіаиійний університет, м. Київ

Проведений аналіз функиіональної активності нейтрофілів і макрофагів. Показано,що будучи ефекторами природної резистентності в імунній системі їх функиї відрізняються. Нейтрофили - ие своєрідні хелпери для макрофагів. Вони підсилюють їх фагочитарну, антигенпрезентуючу та імунорегуляторну функиї.

Ключові слова: нейтрофіли, макрофаги, резистентність, імунна система. 